\title{
Synergistic Effect of Phosphine and Carbon Dioxide on the Mortality of Tribolium castaneum (Coleoptera: Tenebrionidae) in Paddy
}

\author{
R. Meenatchi ${ }^{1}$, R. P. S. J. Alice ${ }^{1} \&$ P. P. Paulin ${ }^{1}$ \\ ${ }^{1}$ Indian Institute of Food Processing Technology, Tamil Nadu, India \\ Correspondence: R. Meenatchi, Indian Institute of Food Processing Technology, Thanjavur, Tamil Nadu-613005, \\ India. Tel: 91-975-096-8420. E-mail: meena@iifpt.edu.in
}

Received: January 3, 2018

Accepted: March 17, $2018 \quad$ Online Published: June 15, 2018

doi:10.5539/jas.v10n7p503

URL: https://doi.org/10.5539/jas.v10n7p503

\begin{abstract}
Phosphine $\left(\mathrm{PH}_{3}\right)$ is widely used as a fumigant for the control of stored product pests. Indiscriminate use of $\mathrm{PH}_{3}$ leads to the development of resistant strains. Thus, an experiment was conducted in a laboratory scale fumigation chamber to determine the synergistic effect of carbon dioxide $\left(\mathrm{CO}_{2}\right)$ and $\mathrm{PH}_{3}$ on the mortality of Tribolium castaneum during fumigation of paddy. $\mathrm{PH}_{3}$ gas generation varies depending upon grain moisture content and dosage of $\mathrm{PH}_{3}$ used for fumigation treatment. Thus, the maximum $\mathrm{PH}_{3}$ concentration with respect to saturation time was achieved when paddy were treated with $98 \% \mathrm{CO}_{2}+3 \mathrm{ppm} \mathrm{PH}_{3}$ at $17 \%$ moisture content, leading to a quick mortality of different life stages of $T$. castaneum with minimum $\mathrm{LT}_{50}$ and $\mathrm{LT}_{99}$ value. Among the different stages of T. castaneum, pupal stage was more resistant to all the treatments compared to larva and adult stages. $\mathrm{PH}_{3}$ residues in all the treatments were below the recommended level and it can be considered as safe for consumption.
\end{abstract}

Keywords: paddy, moisture, phosphine, generation rate, mortality, T. castaneum

\section{Introduction}

India handles more than 200 million tons (MT) of food grains annually. These grains need to be preserved using the available fumigants. Paddy and wheat are commonly stored in warehouses in large quantities and are often infested with $T$. castaneum due to inappropriate storage and handling. To prevent infestation grains are generally fumigated with aluminum phosphide tablets for more than two decades. However, due to unscrupulous and continuous usage of aluminum phosphide resulted in high level pest resistance to phosphine in stored products (Mau et al., 2012). Mixture of $\mathrm{CO}_{2}$ and $\mathrm{PH}_{3}$ is considered as a potential fumigant for the management of stored product pests (Leelaja et al., 2007; Valmas \& Ebert, 2006). Carbon dioxide $\left(\mathrm{CO}_{2}\right)$ a potential gaseous fumigant toxic to insects at high concentration and requires large exposure time for achieving mortality of all the stage $3 \mathrm{~s}$ of insects (Hasan et al., 2016). Many studies show that the addition of Co2 to PH3 enhances the toxicity of PH3 and reduces the dose required to kill insects (Ren et al., 1994). The combination of $\mathrm{CO}_{2}$ with $\mathrm{PH}_{3}$ increases the penetration rate of the fumigant, acts as the propellent for delivering $\mathrm{PH}_{3}$, enhances the respiration rate of insects and is more effective than existing solid formulations available in the market (Leesch, 1992). A combination of $\mathrm{CO}_{2}$ and $\mathrm{PH}_{3}$ is available in the trade name of $\mathrm{ECO}_{2} \mathrm{FUME}{ }^{\circledR}$ and are used in countries such as Australia, New Zealand, North America and Europe (Tumambing et al., 2012). It consists of cylinderized compressed gas formulation containing a mixture of $2 \% \mathrm{PH}_{3}$ by weight ( $2.6 \%$ by volume) in $\mathrm{CO}_{2}$ ( $98 \%$ by weight). Another recently introduced fumigant for the management of stored product pest is $\mathrm{VAPORPH} \mathrm{H}_{3} \mathrm{OS}\left(99.3 \%\right.$ pure $\mathrm{PH}_{3}$ mixed with air). These formulations are considered to be safe, effective and are user friendly for fumigating food and non-food commodities (Meenatchi \& Alagusundaram, 2014). But due to stringent rules in importing and the non-availability of any other chemicals for fumigation other than $\mathrm{PH}_{3}$, none of the fumigants were registered in India. At this juncture, a study was undertaken by using $\mathrm{PH}_{3}$ and $\mathrm{CO}_{2}$ combinations to evaluate the synergistic effect of $\mathrm{PH}_{3}$ with respect to saturation time, $\mathrm{PH}_{3}$ generation in paddy and mortality of $T$. castaneum.

\section{Materials and Methods}

\subsection{Conditioning Paddy}

The paddy was procured with the initial moisture content of $12.5 \%$ wet basis (w.b.) and conditioned to the required moisture content of 11,14 and $17 \%$. To obtain lower moisture content, samples were spread in thin 
layer under shade for natural air drying for about $8 \mathrm{~h}$. To increase the moisture content, samples were conditioned by adding required amount of distilled water and mixed well by passing through a screw conveyor. The amount of water to be added to increase grain moisture content was calculated by using the following Equation (1). The conditioned grain samples were stored in sealed polythene bags in a deep freezer at $-5 \pm 2{ }^{\circ} \mathrm{C}$.

Amount of water added,

$$
K g=W_{s} X \frac{M_{f}-M_{i}}{100-M_{f}}
$$

Where, $\mathrm{W}_{\mathrm{s}}$ : Sample weight $(\mathrm{Kg}) ; \mathrm{M}_{\mathrm{f}}$ : Final moisture content (\% w.b.); $\mathrm{M}_{\mathrm{i}}$ : Initial moisture content (\% w.b.)

\subsection{Culturing of Test Insects}

T. castaneum was cultured and maintained at the Storage Engineering Laboratory at IIFPT, Thanjavur. Insects were cultured at $30{ }^{\circ} \mathrm{C}$ and $70 \%$ RH. Different stages of insects such as pupa, larva and adults were maintained separately to carry out mortality studies.

\subsection{Lab Model Fumigation Set up for Toxicity Studies}

Phosphine fumigation lab model set up was designed and fabricated at Indian Institute of Food Processing Technoloy (IIFPT). It consists of a circular outer acrylic cylindrical tube with the dimension of $37 \times 27 \mathrm{~cm}(\mathrm{ht} \times$ $\varnothing)$ which is pasted in a flat acrylic at the bottom (Figure1). Inside the fumigation chamber, four compartments were made by partitioning it with wire mesh and were fitted in a stand. Fumigation cups of $4 \times 6 \mathrm{~cm}(\mathrm{ht} \times \varnothing)$ were made by cutting small acrylic tubes and were pasted with fine wire mesh at the bottom. The top of the fumigation setup was covered with PVC end cap to make it air tight. Rubber septum was placed at the top cover for injecting $\mathrm{PH}_{3}$. Provisions were made for injecting and releasing $\mathrm{CO}_{2}$ from the cylinder (Meenatchi et al., 2015). Required volume of $\mathrm{PH}_{3}$ gas was calculated and injected into the fumigation chamber using Hamilton syringe through the rubber septum located at the top of the fumigation chamber. The $98 \% \mathrm{CO}_{2}$ in air was continuously flowed through the chamber.

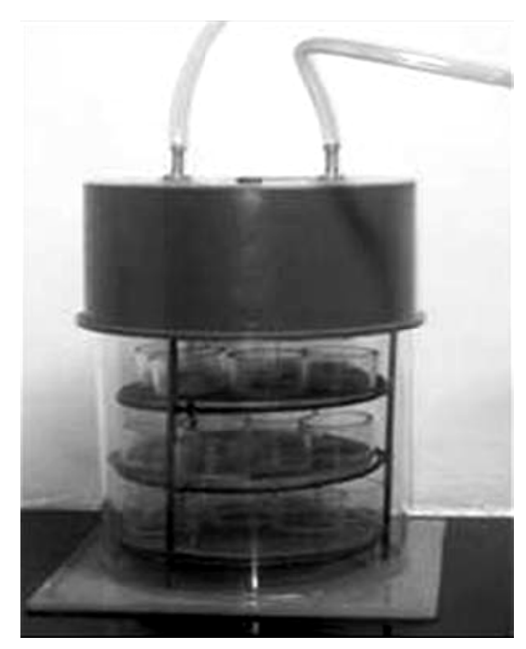

Figure 1. Acrylic fumigation chamber

\subsection{Measurement of $\mathrm{PH}_{3}$ Concentration}

Phosphine concentration was measured using $250 \mathrm{PM}+$ portable phosphine monitor (Uniphos Envirotronic Pvt $\mathrm{Ltd}$, India) at every $4 \mathrm{~h}$ interval for a period of $120 \mathrm{~h}$.

\subsection{Bioassay Studies}

Fifteen grams of the conditioned paddy $(11,14$ and 17\% moisture content) were taken in fumigation cups and 10 insects of various life stages were released. The fumigation cup was covered with muslin cloth. After treatment, the insects were transferred into paddy and then kept in environmental chamber maintained at $25{ }^{\circ} \mathrm{C}$ and $60 \%$ RH. The number of different life stages of dead $T$. castaneum was recorded after fumigation at different time intervals and the mortality percentage was calculated. 
In addition to $\mathrm{PH}_{3}$ generation and saturation time, a similar set of experiments were carried out to know the effect of various combinations of fumigant on insect mortality at different time intervals. In this study, $98 \% \mathrm{CO}_{2}$ with 3, 2, and $1 \mathrm{ppm} \mathrm{PH}_{3}$ and $3 \mathrm{ppm} \mathrm{PH}_{3}$ alone was used as a control. From this data $\mathrm{LT}_{50}$ and $\mathrm{LT}_{99}$ value of various life stages of $T$. castaneum were calculated. All experiments were repeated thrice.

\subsection{Determination of $\mathrm{PH}_{3}$ Residues in the Fumigated Paddy}

The fumigated paddy was placed in a tray for ventilation. After 5 days, $15 \mathrm{~g}$ of treated paddy was taken in a 500 $\mathrm{ml}$ conical flask filled with $150 \mathrm{ml}$ distilled water. Then, the flask was sealed using a stopper with silicone septum, $5 \mathrm{ml}$ of HCL was injected through the syringe in the sampling adopter. The flask was kept in an ultrasonic wave-cleaner and shaken for $5 \mathrm{~min}$ and subsequently allowed to stand for $30 \mathrm{~min}$. The headspace analysis was done using Gas Chromatography (GC-14B, Shimadzu Technologies, Columbia, USA).

\subsection{Data Analysis}

The experimental data were fitted to a linear equation, $\mathrm{Y}=\mathrm{aX}+\mathrm{b}$, where $\mathrm{Y}$ is the $\mathrm{PH}_{3}$ concentration and $\mathrm{X}$ is the fumigation time. The results were statistically analysed using Factorial Completely Randomized Design (FCRD) with replication at $\mathrm{p}<0.01$ and $\mathrm{p}<0.05$ level of significance through AGRES software (7.01). Fisher's least significant difference (LSD) test was followed to determine highly significant difference between the treatments and paddy moisture content. Also, probit analysis was carried out for statistically analyzing the mortality of various life stages of T. castaneum ( $\mathrm{LT}_{50}$ and $\mathrm{LT}_{99}$ ) using polo plus software (V. 2.0).

\section{Results and Discussion}

\subsection{Phosphine Concentration and Saturation Time}

Saturation time is the extent to which maximum $\mathrm{PH}_{3}$ concentration generated at a particular point of time. $\mathrm{PH}_{3}$ concentration and saturation time with respect to different treatments and moisture content were depicted in Table 1. It has been observed that at $11 \%$ moisture content, maximum $\mathrm{PH}_{3}$ concentration of $322 \mathrm{ppm}$ was recorded with the corresponding saturation time of $73 \mathrm{~h}$ in the treatment $\mathrm{T}_{1}$ followed by $\mathrm{T}_{2}$ and $\mathrm{T}_{4}$ with the $\mathrm{PH}_{3}$ concentration of $284 \mathrm{ppm}$ and $270 \mathrm{ppm}$ at the saturation time of $61 \mathrm{~h}$ respectively. Treatment $\mathrm{T}_{3}\left(98 \% \mathrm{CO}_{2}+1\right.$ ppm $\mathrm{PH}_{3}$ ) recorded lowest $\mathrm{PH}_{3}$ concentration of $218 \mathrm{ppm}$ with a saturation time of $55 \mathrm{~h}$. At $14 \%$ moisture content, maximum $\mathrm{PH}_{3}$ concentration of $340 \mathrm{ppm}$ with the saturation time of $67 \mathrm{~h}$ was observed in $\mathrm{T}_{1}$ followed by $\mathrm{T}_{2}, \mathrm{~T}_{4}$ and $\mathrm{T}_{3}$ (Table 1). Similarly, at $17 \%$ moisture content maximum $\mathrm{PH}_{3}$ concentration of $351 \mathrm{ppm}$ with the saturation time of $45 \mathrm{~h}$ was recorded. It could be explained by understanding that at higher grain moisture content elevated $\mathrm{PH}_{3}$ concentration released in shorter period. From our studies, it can be concluded that paddy treated with $98 \% \mathrm{CO}_{2}+3 \mathrm{ppm} \mathrm{PH}_{3}$ was considered to be the effective treatment which enhanced $\mathrm{PH}_{3}$ concentration due to the addition of $\mathrm{CO}_{2}$. Comparing all the treatments, least $\mathrm{PH}_{3}$ concentration value of 204 ppm was recorded at $11 \%$ moisture content in the treatment $\mathrm{T}_{3}$. Several studies in the past confirmed that $\mathrm{PH}_{3}$ concentration remains higher with the addition of $\mathrm{CO}_{2}$ (Daolin et al., 2004). Thus, the increase in $\mathrm{PH}_{3}$ concentration and higher grain moisture content influences the concentration at the time of fumigation. $\mathrm{F}$ values of $\mathrm{PH}_{3}$ peak concentration are highly significant $(\mathrm{P} \leq 0.01)$ with respect to moisture contents, and treatments as given in the Table 2 .

Table 1. Effect of different treatments (i.e. $\mathrm{T}_{1}-\left(98 \% \mathrm{CO}_{2}+3 \mathrm{ppm} \mathrm{PH}_{3}\right) ; \mathrm{T}_{2}-\left(98 \% \mathrm{CO}_{2}+2\right.$ ppm $\left.\mathrm{PH}_{3}\right)$; $\mathrm{T} 3-(98 \%$ $\left.\mathrm{CO}_{2}+1 \mathrm{ppm} \mathrm{PH}_{3}\right)$; T4-(3 ppm $\left.\mathrm{PH}_{3}\right)$ ) and grain moisture content on $\mathrm{PH}_{3}$ generation with respect to saturation time. Values are expressed as Mean \pm standard deviations

\begin{tabular}{|c|c|c|c|c|c|c|}
\hline \multirow{2}{*}{ Treatments } & \multicolumn{2}{|c|}{ Moisture content ( $11 \%$ wet basis) } & \multicolumn{2}{|c|}{ Moisture content ( $14 \%$ wet basis) } & \multicolumn{2}{|c|}{ Moisture content ( $17 \%$ wet basis) } \\
\hline & Saturation time (h) & {$\left[\mathrm{PH}_{3}\right](\mathbf{p p m})$} & Saturation time (h) & {$\left[\mathrm{PH}_{3}\right](\mathbf{p p m})$} & Saturation time (h) & {$\left[\mathrm{PH}_{3}\right](\mathbf{p p m})$} \\
\hline $\mathbf{T}_{1}$ & $73 \pm 2.31$ & $322 \pm 0.57$ & $67 \pm 2.31$ & $340 \pm 1.00$ & $45 \pm 2.31$ & $351 \pm 1.00$ \\
\hline $\mathbf{T}_{2}$ & $61 \pm 2.31$ & $284 \pm 1.00$ & $59 \pm 2.31$ & $287 \pm 1.00$ & $49 \pm 2.31$ & $290 \pm 1.10$ \\
\hline $\mathbf{T}_{3}$ & $57 \pm 2.31$ & $204 \pm 0.74$ & $57 \pm 2.31$ & $235 \pm 1.00$ & $55 \pm 2.31$ & $218 \pm 1.53$ \\
\hline $\mathbf{T}_{4}$ & $61 \pm 2.31$ & $270 \pm 1.00$ & $64 \pm 4.62$ & $295 \pm 1.00$ & $53 \pm 1.15$ & $296 \pm 1.60$ \\
\hline
\end{tabular}


Table 2. Analysis of variance for $\mathrm{PH}_{3}$ generation rate and concentration with respect to saturation time $(\mathrm{p}<0.01)$

\begin{tabular}{|c|c|c|c|c|}
\hline Variables & df & Sum of Square & Mean Square & $\mathbf{F}$ \\
\hline \multicolumn{5}{|l|}{$\mathrm{PH}_{3}$} \\
\hline Treatment $(\mathrm{T})^{*}$ & 3 & 52050.97 & 1024.11 & 635.65 \\
\hline Moisture $(\mathrm{M})^{*}$ & 2 & 2048.22 & 17350.32 & 10769.16 \\
\hline TM* (Treatment $\times$ Moisture $)$ & 6 & 2079.77 & 346.62 & 215.14 \\
\hline Error & 24 & 38.66 & 1.61 & 1.0 \\
\hline Total & 35 & 56217.63 & 56217.63 & 996.96 \\
\hline \multicolumn{5}{|l|}{$\mathrm{PH}_{3}$ generation rate } \\
\hline Treatment $(\mathrm{T})^{*}$ & 3 & 17.78 & 5.92 & 8470.41 \\
\hline Moisture (M)* & 2 & 9.22 & 4.61 & 6586.77 \\
\hline TM* (Treatment $\times$ Moisture $)$ & 6 & 5.74 & 0.95 & 1368.12 \\
\hline Error & 24 & 0.01 & 0.0007 & 1.00 \\
\hline Total & 35 & 32.77 & 0.93 & 1337.64 \\
\hline
\end{tabular}

\subsection{Phosphine Generation Rate}

The residual concentration of the $\mathrm{PH}_{3}$ as a function of time was fitted in linear regression to determine the $\mathrm{PH}_{3}$ generation rate. From Figure 2, it can be concluded that at $17 \%$ moisture content, $\mathrm{T}_{1}$ recorded highest $\mathrm{PH}_{3}$ generation rate of $8.32 \mathrm{ppm} / \mathrm{h}$ as compared to other treatments. Similarly, at 14 and $11 \%$ moisture content maximum $\mathrm{PH}_{3}$ generation rate of 5.60 and $4.89 \mathrm{ppm} / \mathrm{h}$ observed in $\mathrm{T}_{2}$ and $\mathrm{T}_{1}$ respectively. $\mathrm{PH}_{3}$ generation rate was lower in paddy treated with $98 \% \mathrm{CO}_{2}+1 \mathrm{ppm} \mathrm{PH}_{3}$. Among the three moisture levels tested, $\mathrm{T}_{1}$ at $17 \%$ moisture content recorded highest $\mathrm{PH}_{3}$ generation rate. This could be explained by understanding that $\mathrm{PH}_{3}$ generates faster at higher moisture levels and the presence $\mathrm{CO}_{2}$ enhances $\mathrm{PH}_{3}$ toxicity due to synergistic effect. The other factors influences $\mathrm{PH}_{3}$ gas generation includes temperature, moisture content and brand of fumigant used (Banks, 1991). Comparing to low moisture grain, high moisture grain stimulates higher $\mathrm{PH}_{3}$ gas generation (Reed \& Pan, 2000). Thus, the difference in moisture levels and treatments given to the paddy significantly $(\mathrm{p}<$ 0.01 ) affected the $\mathrm{PH}_{3}$ generation rate as given in the Table 2 .

\subsection{Phosphine Concentration With Respect to Fumigation Time}

Aluminum phosphide reacts with the moisture present in the atmosphere and produces $\mathrm{PH}_{3}$ gas. This reaction starts slowly, then gradually increases and later declines when the aluminum phosphide is spent. $\mathrm{Rate}$ of $\mathrm{PH}_{3}$ decomposition during fumigation also varies depending upon the moisture and atmospheric conditions (Figure 3). From figure, it has been observed that there was a gradual decrease in $\mathrm{PH}_{3}$ concentration after attaining saturation point in all the treatments of paddy. Adequate moisture is required for the release of the definite toxicant or $\mathrm{PH}_{3}$ in aluminum phosphide. It is clearly shown that the grain moisture content has direct impact on $\mathrm{PH}_{3}$ generation. $\mathrm{PH}_{3}$ release is enhanced at higher moisture content.

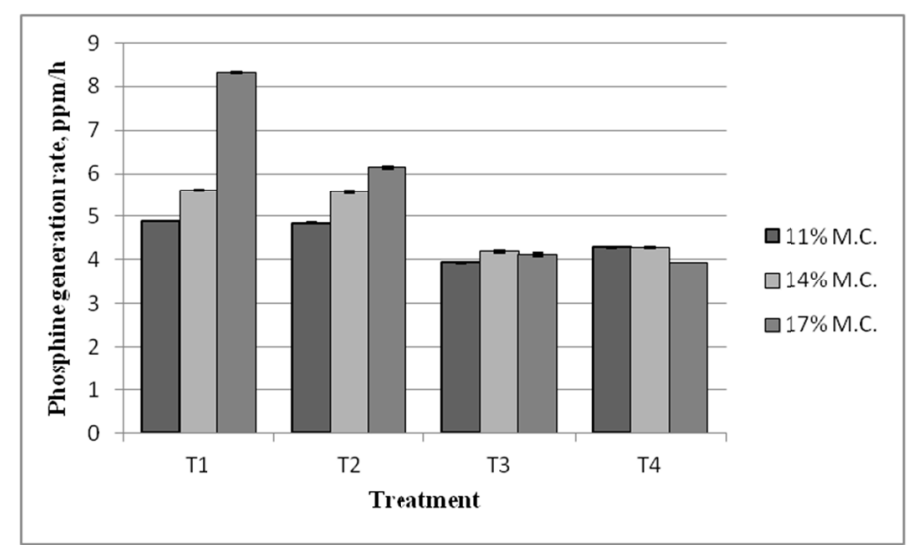

Figure 2. $\mathrm{PH}_{3}$ generation rate in paddy fumigated with $\mathrm{CO}_{2}+\mathrm{PH}_{3}$ at (a) $11 \%$, (b) $14 \%$ and (c) $17 \%$ moisture content (wet basis) during treatments

Note. $\mathrm{T}_{1}-\left(98 \% \mathrm{CO}_{2}+3\right.$ ppm $\left.\mathrm{PH}_{3}\right) ; \mathrm{T}_{2}-\left(98 \% \mathrm{CO}_{2}+2\right.$ ppm $\left.\mathrm{PH}_{3}\right) ; \mathrm{T}_{3}-\left(98 \% \mathrm{CO}_{2}+1\right.$ ppm $\left.\mathrm{PH}_{3}\right) ; \mathrm{T}_{4}-\left(3 \mathrm{ppm} \mathrm{PH}_{3}\right)$. 


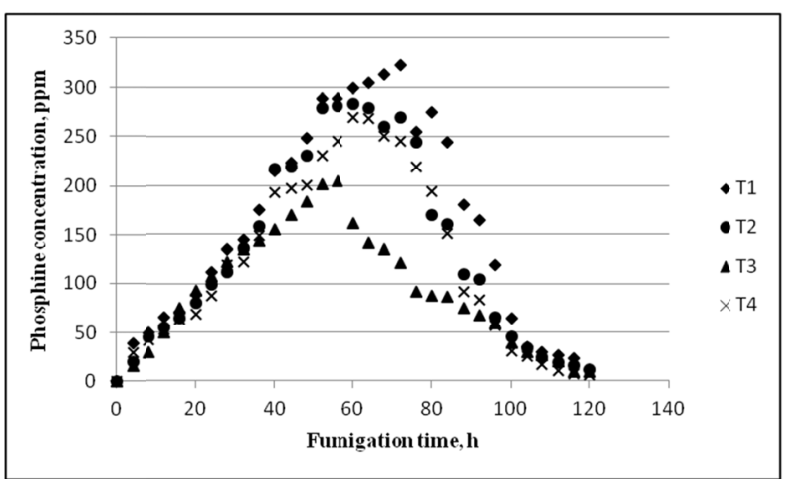

(a)

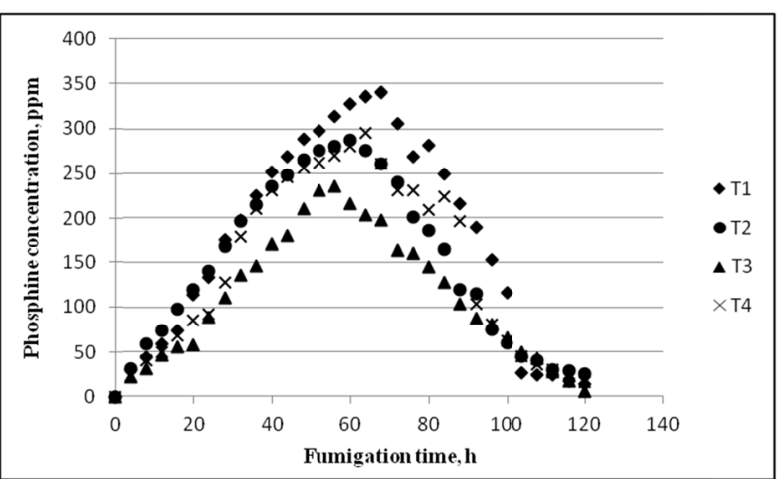

(b)

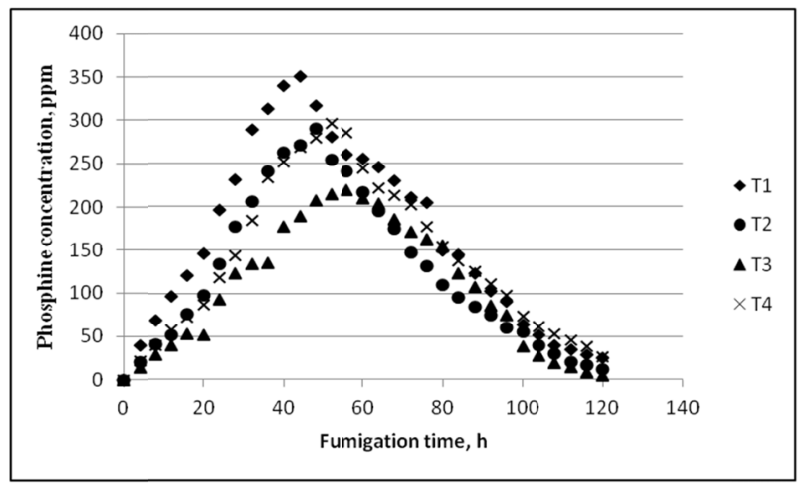

(c)

Figure $3 \mathrm{PH}_{3}$ concentrations in paddy fumigated with $\mathrm{CO}_{2}$ and $\mathrm{PH}_{3}$ at (a) $11 \%$ (b) $14 \%$ and (c) $17 \%$ moisture content (wet basis) during treatments

Note. $\mathrm{T}_{1}-\left(98 \% \mathrm{CO}_{2}+3\right.$ ppm $\left.\mathrm{PH}_{3}\right) ; \mathrm{T}_{2}-\left(98 \% \mathrm{CO}_{2}+2\right.$ ppm $\left.\mathrm{PH}_{3}\right) ; \mathrm{T}_{3}-\left(98 \% \mathrm{CO}_{2}+1\right.$ ppm $\left.\mathrm{PH}_{3}\right) ; \mathrm{T}_{4}-\left(3 \mathrm{ppm} \mathrm{PH}_{3}\right)$.

\subsection{Insect Mortality}

The mixture of $\mathrm{PH}_{3}$ and $\mathrm{CO}_{2}$ significantly affects the mortality of various life stages of $T$. castaneum. The synergistic effect of $\mathrm{CO}_{2}$ on phosphine toxicity is further supported by the fact that, $\mathrm{CO}_{2}$ exerts lethal effects on insects causing their death by dehydration, acidification at the cellular level, and creating a lack of triglycerides for energy metabolism (Busvine, 1971; Adler, 1994; Donahaye, 1991). The $\mathrm{LT}_{99}$ value of T. castaneum in paddy at $11 \%$ moisture content was given in the Table 3 . The minimum lethal time for larva was observed as $27.0 \mathrm{~h}$ in the treatment $T_{1}$, followed by $T_{2}, T_{4}$ and $T_{3}$ with the lethal time of $29.5 \mathrm{~h}, 33.7 \mathrm{~h}$ and $41.9 \mathrm{~h}$ respectively. The $\mathrm{LT}_{99}$ value for pupa and adult was noted as $35.5 \mathrm{~h}$ and $35.6 \mathrm{~h}$ in the treatment $\mathrm{T}_{1}$ and $\mathrm{T}_{2}$ respectively. $\mathrm{LT}_{50}$ for larva, pupa and adult were recorded as $2.9 \mathrm{~h}, 4.8 \mathrm{~h}$ and $1.8 \mathrm{~h}$ respectively. At $14 \%$ moisture content, the minimum $\mathrm{LT}_{99}$ value for larva was $17.1 \mathrm{~h}$ for the treatment $\mathrm{T}_{1}$, followed by adult $21.7 \mathrm{~h}$ and pupa $36.4 \mathrm{~h}$ (Table 4). Similar trend was observed in paddy treated with $\mathrm{CO}_{2}$ and $\mathrm{PH}_{3}$ at $17 \%$ moisture content (Table 5). Among the different treatments, $\mathrm{T}_{1}$ at $17 \%$ moisture content proved as the best treatment recorded with maximum $\mathrm{PH}_{3}$ concentration and minimum lethal time. As the concentration of $\mathrm{PH}_{3}$ increases time taken to achieve $\mathrm{LT}_{50}$ and $\mathrm{LT}_{99}$ decreases. Addition of $\mathrm{CO}_{2}$ to $\mathrm{PH}_{3}$ reduces the time and dose required for fumigation that results in quick insect mortality. Some studies have proven that the addition of $\mathrm{CO}_{2}$ could increase the $\mathrm{PH}_{3}$ concentration and resulted in increased toxicity levels (Donahaye \& Navarro, 1989). Desmarchelier (1984) found that the mixture of phosphine and carbondioxide has synergistic effect on insect mortality as compared to either toxicant alone. The present study also confirmed that addition of $\mathrm{CO}_{2}$ to $\mathrm{PH}_{3}$ enhanced the insect mortality with minimum lethal time. The treatment $T_{1}$ and $T_{2}$ were significantly superior to $T_{3}$ and $T_{4}$ respectively. 
Table 3. Mortality of $T$ castaneum larva, pupa and adult treated with $\mathrm{CO}_{2}+\mathrm{PH}_{3}$ (i.e. $\mathrm{T}_{1}-\left(98 \% \mathrm{CO}_{2}+3 \mathrm{ppm} \mathrm{PH}_{3}\right)$;

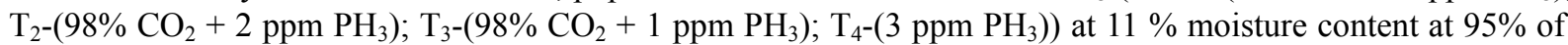
confidential limit

\begin{tabular}{|c|c|c|c|c|c|c|}
\hline Stage & & Slope \pm SE & $\mathbf{L T}_{50}(\mathrm{~h})$ & $\mathbf{L T}_{\mathbf{9 5}}(\mathrm{h})$ & $\mathbf{L T}_{99}(\mathrm{~h})$ & $X^{2}$ (df) \\
\hline \multirow[t]{4}{*}{ Larva } & $\mathrm{T}_{1}$ & $2.4 \pm 0.4$ & $2.9(2.0-3.7)$ & $14.1(10.3-25.3)$ & $27.0(17.1-65.9)$ & $4.7(16)$ \\
\hline & $\mathrm{T}_{2}$ & $2.4 \pm 0.4$ & $3.3(2.4-4.1)$ & $15.6(11.3-28.1)$ & $29.5(18.6-71.7)$ & $8.6(16)$ \\
\hline & $\mathrm{T}_{3}$ & $2.3 \pm 0.4$ & $4.2(3.2-5.2)$ & $21.4(14.7-44.0)$ & $41.9(24.6-118.8)$ & $10.4(16)$ \\
\hline & $\mathrm{T}_{4}$ & $2.2 \pm 0.4$ & $3.2(2.5-4.0)$ & $16.9(11.9-33.4)$ & $33.7(20.1-94.5)$ & $8.5(16)$ \\
\hline \multirow[t]{4}{*}{ Pupa } & $\mathrm{T}_{1}$ & $2.8 \pm 0.3$ & $5.2(4.1-6.3)$ & $20.3(15.3-32.2)$ & $35.5(24.1-69.2)$ & $35.6(25)$ \\
\hline & $\mathrm{T}_{2}$ & $2.3 \pm 0.3$ & $5.7(4.5-6.9)$ & $28.9(20.6-51.3)$ & $56.4(35.19-129.9)$ & $28.8(25)$ \\
\hline & $\mathrm{T}_{3}$ & $2.4 \pm 0.3$ & $7.3(6.1-8.5)$ & $33.7(24.7-55.2)$ & $63.5(41.5-127.2)$ & $24.5(25)$ \\
\hline & $\mathrm{T}_{4}$ & $2.3 \pm 0.3$ & $4.8(3.8-5.7)$ & $24.3(18.3-38.3)$ & $47.5(31.6-92.8)$ & $13.3(25)$ \\
\hline \multirow[t]{4}{*}{ Adult } & $\mathrm{T}_{1}$ & $1.8 \pm 0.4$ & $2.0(0.9-2.9)$ & $15.8(10.4-40.6)$ & $36.6(19.3-174.5)$ & $6.7(16)$ \\
\hline & $\mathrm{T}_{2}$ & $2.1 \pm 0.4$ & $2.8(1.7-3.6)$ & $16.9(11.6-36.6)$ & $35.6(20.3-118.5)$ & $6.3(16)$ \\
\hline & $\mathrm{T}_{3}$ & $2.0 \pm 0.3$ & $3.3(2.2-4.3)$ & $21.8(14.2-53.5)$ & $47.2(25.2-183.1)$ & $8.6(16)$ \\
\hline & $\mathrm{T}_{4}$ & $1.6 \pm 0.4$ & $1.8(0.6-2.7)$ & $17.5(10.9-59.1)$ & $44.7(21.2-347.9)$ & $8.5(16)$ \\
\hline
\end{tabular}

Table 4. Mortality of $T$ castaneum larva, pupa and adult treated with $\mathrm{CO}_{2}+\mathrm{PH}_{3}$ (i.e. $\mathrm{T}_{1}-\left(98 \% \mathrm{CO}_{2}+3 \mathrm{ppm} \mathrm{PH}_{3}\right)$;

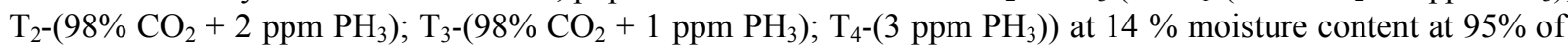
confidential limit

\begin{tabular}{|c|c|c|c|c|c|c|}
\hline Stage & & Slope \pm SE & $\mathbf{L T}_{50}(\mathrm{~h})$ & $\mathbf{L T}_{95}(\mathrm{~h})$ & $\mathbf{L T}_{99}(\mathrm{~h})$ & $X^{2}(d f)$ \\
\hline \multirow[t]{4}{*}{ Larva } & $\mathrm{T}_{1}$ & $2.6 \pm 0.4$ & $2.3(1.5-2.9)$ & $9.5(7.3-15.2)$ & $17.1(11.6-36.0)$ & $5.2(16)$ \\
\hline & $\mathrm{T}_{2}$ & $2.2 \pm 0.4$ & $2.5(1.5-3.3)$ & $13.4(9.6-25.2)$ & $26.7(16.4-73.3)$ & $6.4(16)$ \\
\hline & $\mathrm{T}_{3}$ & $2.2 \pm 0.4$ & $3.3(2.3-4.1)$ & $17.8(12.4-36.3)$ & $35.8(21.1-104.5)$ & $10.6(16)$ \\
\hline & $\mathrm{T}_{4}$ & $2.0 \pm 0.4$ & $2.4(1.3-3.2)$ & $15.1(10.4-32.8)$ & $32.3(18.4-111.9)$ & $5.7(16)$ \\
\hline \multirow[t]{4}{*}{ Pupa } & $\mathrm{T}_{1}$ & $2.6 \pm 0.3$ & $4.7(3.8-5.4)$ & $20.0(15.3-30.4)$ & $36.4(25.0-67.0)$ & $21.7(22)$ \\
\hline & $\mathrm{T}_{2}$ & $2.2 \pm 0.3$ & $5.1(4.1-6.2)$ & $27.4(19.5-48.5)$ & $54.7(33.9-125.4)$ & $20.0(22)$ \\
\hline & $\mathrm{T}_{3}$ & $2.2 \pm 0.3$ & $6.5(5.2-8.0)$ & $35.1(23.2-76.0)$ & $70.3(39.7-210.0)$ & $25.1(22)$ \\
\hline & $\mathrm{T}_{4}$ & $2.2 \pm 0.3$ & $4.4(3.3-5.4)$ & $24.0(17.3-41.4)$ & $48.3(30.3-108.7)$ & $8.2(22)$ \\
\hline \multirow[t]{4}{*}{ Adult } & $\mathrm{T}_{1}$ & $2.0 \pm 0.4$ & $1.5(0.6-2.3)$ & $10.0(7.1-20.8)$ & $21.7(12.7-80.6)$ & $7.2(16)$ \\
\hline & $\mathrm{T}_{2}$ & $2.2 \pm 0.4$ & $2.0(1.1-2.8)$ & $11.3(8.2-21.3)$ & $22.8(14.0-65.6)$ & $8.6(16)$ \\
\hline & $\mathrm{T}_{3}$ & $2.0 \pm 0.4$ & $2.6(1.5-3.4)$ & $16.7(11.3-37.8)$ & $36.1(20.1-130.5)$ & $7.6(16)$ \\
\hline & $\mathrm{T}_{4}$ & $1.7 \pm 0.4$ & $1.4(0.3-2.3)$ & $12.1(7.9-41.0)$ & 29.4(14.6-261.8) & $7.9(16)$ \\
\hline
\end{tabular}

Table 5. Mortality of $T$ castaneum larva, pupa and adult treated with $\mathrm{CO}_{2}+\mathrm{PH}_{3}$ (i.e. $\mathrm{T}_{1}-\left(98 \% \mathrm{CO}_{2}+3 \mathrm{ppm} \mathrm{PH}_{3}\right)$;

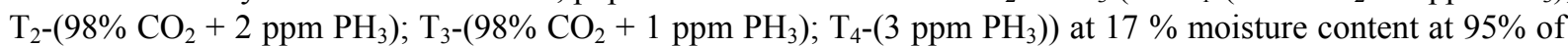
confidential limit

\begin{tabular}{lllllll}
\hline Stage & & Slope \pm SE & $\mathbf{L T}_{\mathbf{5 0}}(\mathbf{h})$ & $\mathbf{L T}_{\mathbf{9 5}} \mathbf{( h )}$ & $\mathbf{L T}_{\mathbf{9 9}} \mathbf{( h )}$ & $\mathbf{X}^{\mathbf{2}} \mathbf{( d f )}$ \\
\hline Larva & $\mathbf{T}_{\mathbf{1}}$ & $2.2 \pm 0.5$ & $1.3(0.3-2.0)$ & $6.9(2.0-5.0)$ & $13.8(8.3-58.1)$ & $6.4(13)$ \\
& $\mathbf{T}_{\mathbf{2}}$ & $2.0 \pm 0.5$ & $1.3(0.4-2.1)$ & $8.2(5.8-19.3)$ & $17.5(10.1-84.9)$ & $3.3(13)$ \\
& $\mathbf{T}_{\mathbf{3}}$ & $1.9 \pm 0.5$ & $1.6(0.6-2.5)$ & $11.3(7.6-31.8)$ & $25.0(13.3-147.4)$ & $6.0(13)$ \\
& $\mathbf{T}_{\mathbf{4}}$ & $1.5 \pm 0.4$ & $1.1(0.09-2.1)$ & $14.3(8.2-131.3)$ & $40.3(16.2-2368.4)$ & $8.0(13)$ \\
\hline Pupa & $\mathbf{T}_{\mathbf{1}}$ & $2.4 \pm 0.3$ & $3.8(2.7-4.8)$ & $18.2(13.1-33.0)$ & $34.6(21.7-84.7)$ & $29.4(22)$ \\
& $\mathbf{T}_{\mathbf{2}}$ & $2.0 \pm 0.3$ & $3.7(2.4-4.8)$ & $24.6(16.4-54.3)$ & $53.6(29.8-178.6)$ & $25.5(22)$ \\
& $\mathbf{T}_{\mathbf{3}}$ & $2.3 \pm 0.3$ & $5.7(4.7-6.8)$ & $29.3(20.9-51.8)$ & $57.4(35.8-129.7)$ & $20.4(22)$ \\
& $\mathbf{T}_{\mathbf{4}}$ & $2.1 \pm 0.3$ & $4.0(2.9-4.9)$ & $23.3(16.7-41.2)$ & $48.2(29.8-113.3)$ & $10.5(22)$ \\
& $\mathbf{T}_{\mathbf{1}}$ & $2.2 \pm 0.5$ & $1.6(0.7-2.3)$ & $8.9(6.4-19.0)$ & $18.0(10.7-67.0)$ & $2.7(13)$ \\
& $\mathbf{T}_{\mathbf{2}}$ & $2.2 \pm 0.5$ & $2.0(1.0-2.7)$ & $10.4(7.4-22.2)$ & $20.7(12.3-71.9)$ & $3.6(13)$ \\
& $\mathbf{T}_{\mathbf{3}}$ & $1.9 \pm 0.4$ & $2.4(1.2-3.3)$ & $16.4(10.4-50.8)$ & $36.2(18.3-213.5)$ & $7.6(13)$ \\
& $\mathbf{T}_{\mathbf{4}}$ & $2.1 \pm 0.4$ & $1.9(0.9-2.7)$ & $11.7(7.9-29.2)$ & $24.6(13.6-112.3)$ & $6.2(13)$ \\
\hline
\end{tabular}




\section{Conclusion}

From the above work it can be concluded that the use of combination of $\mathrm{PH}_{3}$ and $\mathrm{CO}_{2}$ is more effective than $\mathrm{PH}_{3}$ fumigation alone. The mixture of $\mathrm{CO}_{2}$ and $\mathrm{PH}_{3}$ increased the $\mathrm{PH}_{3}$ concentration and generation rate during

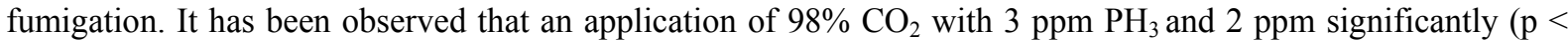
0.01) improve the fumigation process by increasing $\mathrm{PH}_{3}$ concentration and generation rate. Fumigating paddy with $98 \% \mathrm{CO}_{2}+1 \mathrm{ppm} \mathrm{PH}_{3}$ showed reduced effectiveness as compared to control treatment. The presence of $\mathrm{CO}_{2}$ is also essential during fumigation which causes suffocation to insects and results in quick mortality of insects in modified atmospheric storage (Alice et al., 2015). Addition of $\mathrm{CO}_{2}$ to $\mathrm{PH}_{3}$ enhanced the toxicity of $\mathrm{PH}_{3}$ and significantly reduces the $\mathrm{LT}_{50}$ and $\mathrm{LT}_{99}$ values. The average $\mathrm{PH}_{3}$ concentration required for the mortality of Tribolium castaneum (adult, pupa and larva) at different grain paddy moisture content was determined. However, egg mortality has to be studied for the above mentioned treatments to prevent reinfestation of insects during storage. $\mathrm{PH}_{3}$ residues in all the treatments including control were recorded below the recommended level $(0.1$ ppm). Hence it is considered as safe for consumption in all the treatments including control.

\section{Acknowledgements}

The authors gratefully acknowledge Department of Science \& Technology (DST), Science and Engineering Research Board (SERB) and Ministry of Food Processing Industries (MoFPI) for funding the scheme and Director, IIFPT for the support and guidance.

\section{References}

Alice, R. P., Sujeetha, J., Meenatchi, R., Venkatesan, P., \& Brimapureeswaran, R. (2015). Nitrogen based modified atmosphere for the management of Cigarette beetle, Lasioderma serricorne in turmeric. International Journal for Science and Advance Research in Technology, 1(11), 84-87.

Banks, H. J. (1991). Influence of water and temperature on release of phosphine from aluminium phosphide-containing formulations. Journal of Stored Products Research, 27, 41-56. https://doi.org/ 10.1016/0022-474X(91)90031-7

Daolin, G., Xiaoping, Y., Zhanggui, Q., Longde, Y., Zili, Y., \& Tianke, J. (2004). Using carbon dioxide to enhance the efficacy of phosphine fumigation. In E. J. Donahaye, S. Navarro, C. Bell, D. Jayas, R. Noyes, \& T. W. Phillips (Eds.), Proc. Int. Conf. Controlled Atmosphere and Fumigation in Stored Products (pp. 485-492). Gold-Coast Australia, FTIC Ltd. Publishing, Israel.

Desmarchelier, J. M. (1984). Effect of carbon dioxide on the efficacy of phosphine against different stored product pests (No. 220, p. 57). Federal Biological Research Centre for Agriculture and Forestry, Berlin.

Donahaye, E., \& Navarro, S. (1989). Sensitivity of two dried fruit pests to methyl bromide alone, and in combination with carbon dioxide or under reduced pressure. Tropical Science, 29, 9-14.

Hasan, M. M., Aikins, M. J., Schilling, W., \& Phillips, T. W. (2016). Efficacy of controlled atmosphere treatments to manage arthropod pests of dry-cured hams. Insects, 7(3), 44. https://doi.org/10.3390/ insects 7030044

Leelaja, B. C., Rajashekar, Y., Reddy, P. V., Begum, K., \& Rajendran, S. (2007). Enhanced fumigant toxicity of allyl acetate to stored-product beetles in the presence of carbon dioxide. Journal of Stored Products Research, 43, 45-48. https://doi.org/10.1016/j.jspr.2005.09.004

Leesch, J. G. (1992). Carbon dioxide on the penetration and distribution of phosphine through wheat. $J$ Econ. Entomol, 85, 157-161. https://doi.org/10.1093/jee/85.1.157

Mau, Y. S., Collins, P. J., Daglish, G. J., Nayak, M. K., \& Ebert, P. R. (2012). The rph2 gene is responsible for high level resistance to phosphine in independent field strains of Rhyzopertha dominica. PLoS ONE, 7, e34027. https://doi.org/10.1371/journal.pone.0034027

Meenatchi, R., \& Alagusundaram, K. (2014). The current status of fumigation in India: Constrains and recent developments. Trends in Entomology, 10, 97-103.

Meenatchi, R., Brimapureeswaran, R., Alagusundaram, K., \& Sujeetha, A. R. P. (2015). Design and development of carbon dioxide fumigation setup with automatic gas controlling system for safe storage of grains. International Journal of Emerging Technology and Innovative Engineering, 1(6), 29-32.

Rajendran, S. (2001). Alternatives to methyl bromide as fumigants for stored food commodities. Pesticide Outlook, 12(6), 249-253. https://doi.org/10.1039/B110550G 
Reed, C., \& Pan, H. (2000). Loss of phosphine from unsealed bins of wheat at six combinations of grain temperature and grain moisture content. Journal of Stored Products Research, 36, 263-279. https://doi.org/ 10.1016/S0022-474X(99)00049-1

Ren, Y. L., O'Brien, I. G., \& Whittle, G. P. (1994). Studies on the effect of carbon dioxide in insect treatment with phosphine. In E. Highley, E. J. Wright, H. J. Banks, \& B. R. Champ (Eds.), Proc. of the $6^{\text {th }}$ Int. Working Conf. on Stored-product Protection, 17-23 April 1994 (pp. 173-177). Canberra, CAB, Wallingford, UK.

Riudavets, J., Castañé, C., Alomar, O., Pons, M. J., \& Gabarra, R. (2010). The use of carbon dioxide at high pressure to control nine stored-product pests. Journal of Stored Products Research, 46, 228-233. https://doi.org/10.1016/j.jspr.2010.05.005

Tumambing, J., Depalo, M., Garnier, J. P., \& Mallari, R. (2012). $\mathrm{ECO}_{2}$ Fume and Vaporph $\mathrm{OS}_{3}$ phosphine fumigants-Global application updates. In S. Navarro, H. J. Banks, D. S. Jayas, C. H. Bell, R. T. Noyes, A. G. Ferizli, M. Emekci, A. A. Isikber, \& K. Alagusundaram (Eds.), Proc. of the $9^{\text {th }}$ Int. Conf. on Controlled Atmosphere and Fumigation in Stored Products, 15-19 October 2012 (pp. 363-373). Antalya, Turkey, ARBER Professional Congress Services, Turkey.

Valmas, N., \& Ebert, P. R. (2006). Comparative toxicity of fumigants and a phosphine synergist using a novel containment chamber for the safe generation of concentrated phosphine gas. PloS ONE, 1 , e130. https://doi.org/10.1371/journal.pone.0000130

Williams, P. (1985). Toxicity of methyl bromide in carbon dioxide enriched atmospheres to beetles attacking stored grain. General Applied Entomology, 17, 17-24.

\section{Copyrights}

Copyright for this article is retained by the author(s), with first publication rights granted to the journal.

This is an open-access article distributed under the terms and conditions of the Creative Commons Attribution license (http://creativecommons.org/licenses/by/4.0/). 